\title{
Commentary: The value of a surprise
}

\author{
Alden H. Harken, MD
}

From the University of California, San Francisco, East Bay (Retired), Oakland, Calif. Disclosures: Author has nothing to disclose with regard to commercial support.

Received for publication Sept 16, 2019; revisions received Sept 16, 2019; accepted for publication Sept 16, 2019; available ahead of print Oct 3, 2019.

Address for reprints: Alden H. Harken, MD, University of California, San Francisco, East Bay (Retired), 1565

Alamo Way, Alamo CA 94507 (E-mail: alden.harken68@gmail.com).

J Thorac Cardiovasc Surg 2021;161:e17

0022-5223/ $\$ 36.00$

Copyright (C) 2019 Published by Elsevier Inc. on behalf of The American Association for Thoracic Surgery

https://doi.org/10.1016/j.jtcvs.2019.09.111

Urotensin is a dodecapeptide somatostatin analog that stimulates sodium and potassium absorption across intestinal mucosal. Urotensin is present in cardiac atrial, ventricular, and arterial muscle, but not venous vascular muscle. The group from McGill University have previously looked for, and found, urotensin in the atherosclerotic plaques of coronary arteries. Urotensin's sibling, somatostatin, functions primarily to regulate and inhibit other hormones, such as glucagon, insulin, and gastrin.

So, does it make sense to look for a primarily gastrointestinal inhibitory peptide in stenotic aortic valves? Khan and colleagues $^{1}$ from the McGill group report in their article in this issue of the Journal that they examined 61 blocksectioned aortic valves, 5 aortic normal valves from unused donor hearts, and 31 calcified aortic valves obtained at surgery. They report the abundant presence of urotensin II, urotensin-related peptide, and urotensin receptor, as identified by immune staining, in the calcified valves relative to the healthy leaflets. Then, with an eye toward Koch's postulates, Khan and colleagues ${ }^{1}$ treated human aortic interstitial cells with urotensin II and urotensin-related peptide and demonstrated a robust increase in cell proliferation, with a coincident decrease in cholesterol efflux from these cells.

So, at this point, Khan and colleagues ${ }^{1}$ have identified the suspect who is holding a weapon capable of inflicting harm; however, they do not yet have a video of the suspect standing beside, or actually shooting, the dead teller on the floor of the bank. Their stated goal is to suggest a plausible medical therapy for patients with aortic stenosis. So, before legislating against all guns (or urotensins) they sought additional circumstantial evidence. Diabetes does cause (or is certainly closely associated with) vascular disease.

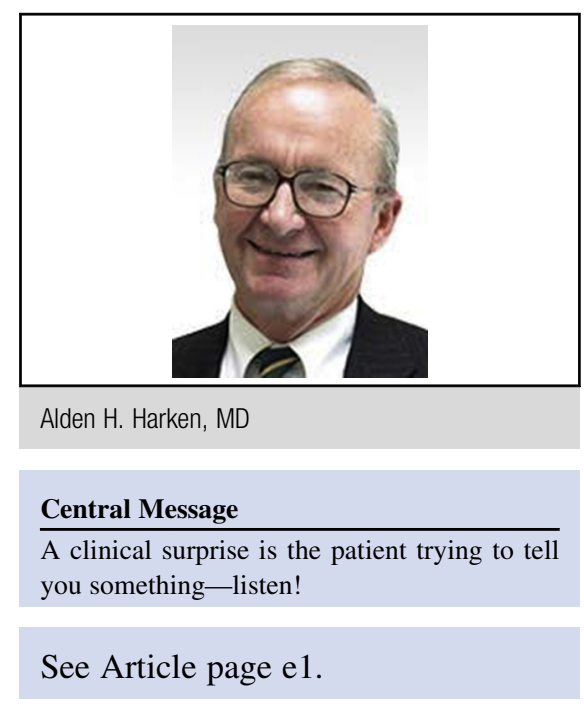

Diabetes does upregulate urotensin II and its receptor, which stimulate transforming growth factor $\beta 1$ to promote fibrosis. Urotensin II staining is increased in patients with diabetes undergoing carotid endarterectomy, and a urotensin receptor antagonist appears to protect against streptozotocin-induced vascular disease in mice. The same group has previously published evidence that blocking urotensin II receptor ameliorates the metabolic syndrome and improves cardiac function in obese mice. ${ }^{2}$ At least metabolically and pathophysiologically, the evidence in favor of convicting urotensins is mounting.

It is safe to say that all pharmacologic agents carry unsuspected effects along with their intended therapies. The urostatin family certainly does influence fluid absorption across the intestinal wall. But, Khan and colleagues, ${ }^{1}$ to my delight and surprise, appear to have identified a mechanistic target and potential medical therapy in which the patient can know that he or she may need only tolerate a little diarrhea as the aortic stenosis resolves.

\section{References}

1. Khan K, Albanese I, Yu B, Shalal Y, Al-Kindi H, Alaws H, et al. Urotensin II, urotensin-related peptide, and their receptor in aortic valve stenosis. J Thorac Cardiovasc Surg. 2021;161:e1-15.

2. You Z, Al Kindi H, Abdul-Karim A, Barrette PO, Schwertani A. Blocking the urotensin II receptor pathway ameliorates the metabolic syndrome and improves cardiac function in obese mice. FASEB J. 2014;28:1210-20. 